\title{
THE AGE AND LOCALIZATION OF KIMBERLITE MAGMATISM IN THE YAKUTIAN KIMBERLITE PROVINCE - CONSTRAINTS FROM ISOTOPE GEOCHRONOLOGY
}

\author{
Smelov AP. ${ }^{{ }^{*}}$ and Zaitsev AI. ${ }^{1}$ \\ Diamond and Precious Metal Geology Institute, Siberian Branch, Russian Academy of Sciences, 39 Lenin \\ Avenue, Yakutsk, 677980, Russian Federation \\ *corresponding author (a.p.smelov@diamond.ysn.ru)
}

\section{Introduction}

The Yakutian kimberlite province (YKP) occupies the northeastern part of the Siberian platform within the North Asian craton (Fig. 1). The YKP extends northwards for about $1500 \mathrm{~km}$ from the Vilyui R. to the Laptev Sea and easterly for $1000 \mathrm{~km}$ from the Olenek R. head in Krasnoyarsk Territory to the Lena R. in Yakutia (Russia) (Khar'kiv et al., 1998). The province is bounded on the north and east by the Lena-Anabar and Priverkhoyansk basins and on the southeast by the Vilyui syneclise and the Angara-Vilyui basin. The western boundary is less well defined, and runs along the eastern slope of the Tunguska synclise. Over the last 50 years, some 1070 kimberlite bodies have been discovered within the YKP territory, which are united into 24 kimberlite fields (Brakhfogel', 1984; Ilupin et al., 1990; Khar'kiv et al., 1998). Hundreds of scientific papers on the mineral content of diamondiferous kimberlites, their tectonic setting, composition of the mantle substrate, physical properties of diamonds, and composition of their mineral inclusions have been published. However, little attention was given to the analysis of isotope data available for kimberlites, though they yield important information not only about the timing of kimberlite magmatism but about the isotopic composition of mantle protoliths and the processes responsible for the diamond tenor and occurrences of kimberlites too.

\section{Geology}

The YKP is divided into two subprovinces: the southern Vilyui subprovince in the center of the Siberian platform and the northern Anabar-Olenek subprovince in the northeastern margin of the platform (Fig. 1). Their kimberlites differ in a number of features. Kimberlites from the Vilyui subprovince are mainly of explosive type. Northward there is an increase in the number of intrusive bodies unevenly distributed amidst the explosive ones. The overall amount of kimberlite bodies in the Anabar-Olenek subprovince is 4.5 times higher than in the Vilyui one, but their diamond tenor is $90 \%$ lower. The diamond morphology and size also differs in the two subprovinces. All the kimberlite fields occur within a limited number of mineragenic (kimberlite-controlling) zones.

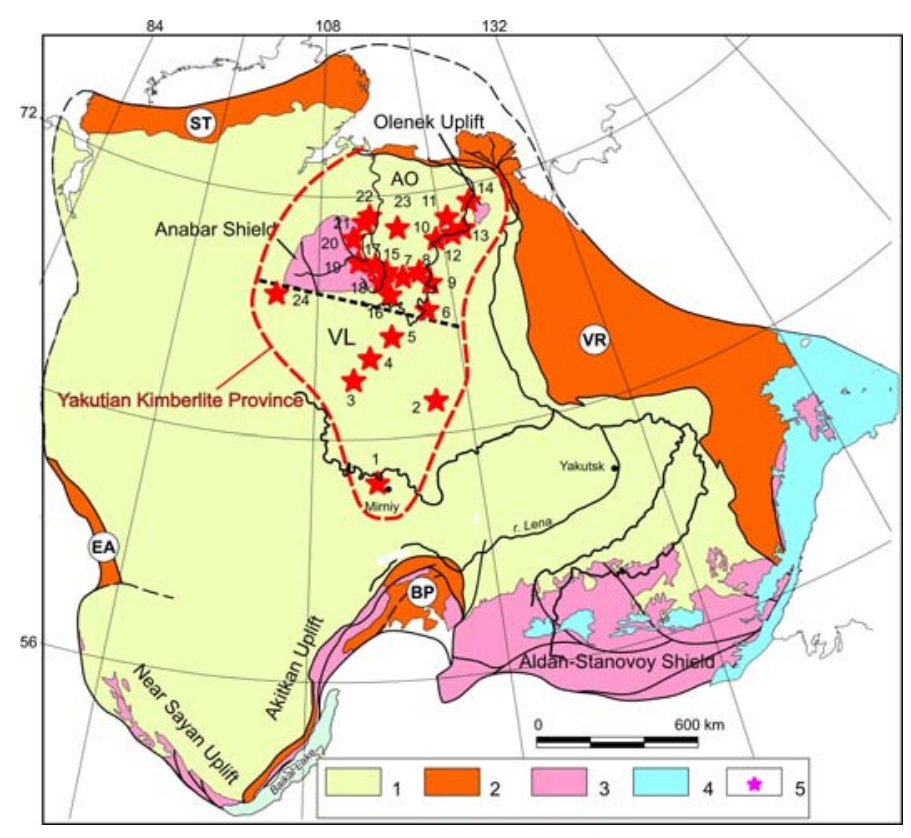

Fig.1. Tectonic sketch map of the North Asian craton (Smelov, Timofeev, 2007) showing position of the Yakutian kimberlite province: 1 - Siberian platform; 2 - subsided craton margin, foldand-thrust belts (ST - South Taimyr, EA - East Angara, BP - BaikalPatom, VR - Verkhoyansk); 3 - Precambrian basement (shields and uplifts); 4 - Mesozoic volcanogenic belt; 5 - kimberlite fields: 1 Malo-Botuobiya, 2 - Nakyn, 3 - Alakit-Markha, 4 - Daldyn, 5 Upper Muna, 6 - Chomurdakh, 7 - West Ukukit, 8 - East Ukukit, 9 Ogoner-Yuryakh, 10 - Merchemde, 11 - Kuoyka, 12 - Molodo, 13 Toluopka, 14 - Khorbosuonka, 15 - Luchakan, 16 - Kuranakh, 17 Dyuken, 18 - Biriginde, 19 - Ary-Mastakh, 20 - Starorechenskoye, 21 - Orto-Yarga, 22 - Ebelyakh, 23 - Tomtor, 24 - Kharamay. VL Vilyui and AO - Anabar-Olenek subprovinces.

\section{Methods}

The number of kimberlite magmatism epochs within the YKP has been discussed repeatedly. Different authors define them differently. Brakhfogel' (1984) was the first to review the existing data on the age of kimberlite magmatism within the YKP. He found that according to different researchers the 


\section{0't Intemational Kimberlite Conference-2012}

number of epochs varied from 1 to 5 (from Late Ordovician through Cretaceous). At that time it was difficult to determine more precisely the timing of kimberlite magmatism because of the lack of reliable geological data and insufficient isotope dates available for the rocks and minerals. Over the last two decades, numerous age determinations were obtained for kimberlites using different radiological methods ( $\mathrm{Rb}-\mathrm{Sr}$ and $\mathrm{K}-\mathrm{Ar}$ on the rock and minerals, U-Pb on zircon and perovskite, apatite and zircon fission track analysis). The central problem with isotope dating of kimberlites and interpretation of the ages obtained is that the rocks themselves represent a heterogeneous mixture of restite, protomagmatic, xenogenic and late magmatic minerals. With all their merits, different isotope methods do not always yield real geological ages of the kimberlite emplacement and thus they should be used in combination. The results of comparative analysis of more than 900 isotope age determinations of kimberlites from 24 fields led us to the following results (Zaitsev, Smelov, 2010).

\section{Results}

According to modern isotope dating, 7 epochs of kimberlite formation can confidently be recognized within the YKP: 450-430, 420-400, 380-350, 250-230, 170-150, 110-100 and 60-50 Ma (Fig. 2).

Older isotope dates of kimberlites are also available, which together with the $\mathrm{U}-\mathrm{Pb}$ zircon ages obtained from diamondiferous intermediate sedimentary collectors are indicative of the Vendian and Early Ordovician epochs of kimberlite magmatism in some regions of the province. It is established that in different parts of the Siberian platform, irrespective of the age of the basement, the number of kimberlite formation epochs (including diamondiferous kimberlites) varies from 2 to 7 . The least number of epochs (Ordovician-Silurian and Devonian-Carboniferous) is observed in the Vilyui subprovince, while in the AnabarOlenek subprovince from 2 to 7 stages are established in different fields. Distribution areas of kimberlite magmatism (including diamondiferous kimberlites) do not correlate with the age and composition of the Early Precambrian basement (Fig. 3).

Fig.4 shows the distribution areas of kimberlite magmatism and diamond tenor of kimberlites in different periods of the Siberian platform development. Analysis of the kimberlite magmatism distribution in different time spans showed that Paleozoic epochs of kimberlite formation are mainly characteristic of the western part of the YKP (Fig. 4, A-B).

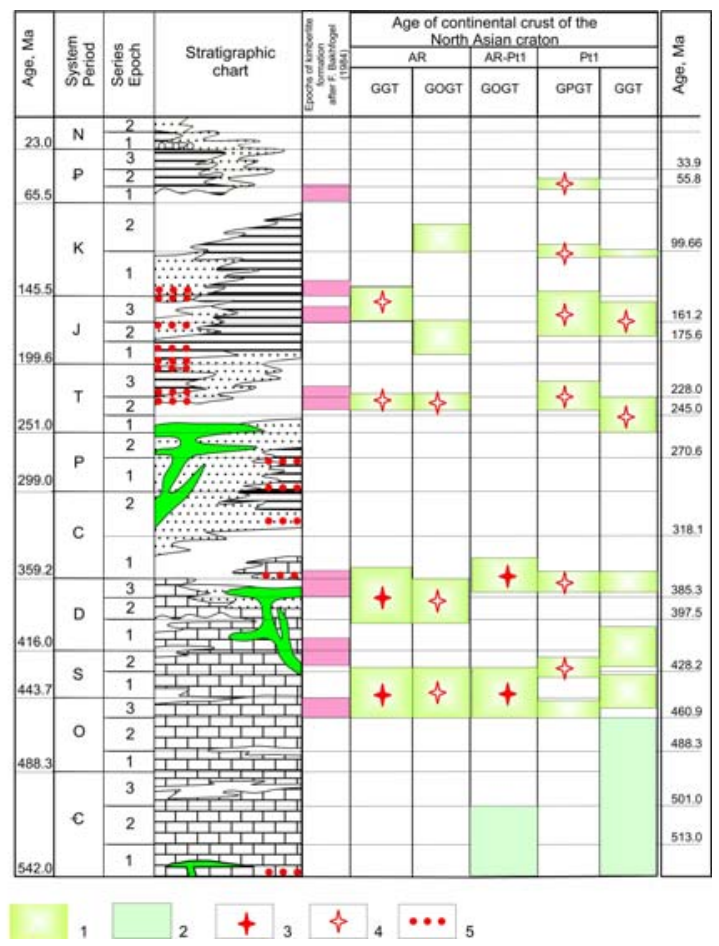

Fig. 2. Age epochs of kimberlite formation, diamond tenor, age and composition of terranes of the basement of the Siberian platform: Epochs of kimberlite formation (1-2): 1 - defined, 2 - assumed; epochs of diamondiferous kimberlite magmatism (3-4): 3 - highgrade diamond (commercial) kimberlites, 4 - low-grade diamond kimberlites, 5 - occurrences of kimberlite indicator minerals. Terranes of the Siberian platform basement: GGT - granitegreenstone, GOGT - granulite-orthogneiss, GPGT - granuliteparagneiss.

It should be noted that the eastern boundary of the kimberlite magmatism area coincides with or is close to the western boundary of the Devonian rift-related structures and dike swarms developed in the eastern North Asian craton. It is established that Mesozoic high-grade kimberlites occur to the south of the Meso- and Neoproterozoic paleorifts boundary. It is likely that endogenic activities related to the breakup of the Rodinia supercontinent in the Precambrian led to degradation of the diamondiferous mantle keel. Mesozoic kimberlite magmatism manifested itself in the northern Siberian platform northeastward of the areas of intense trap magmatism. Different configuration, size and location of the areas of different-aged kimberlite magmatism (Fig.4, A-E) likely indicate their different geodynamic nature. The presence of different-aged kimberlites within the same mineragenic zones may be related to the formation of the basement relief because the zones themselves are confined to peripheral parts of the basement uplifts. In conclusion, it should be noted that the problems of tectonic control of kimberlite magmatism and its

\section{Extended Abstract}

1 


\section{0th Intemational Kimberlite Conference-2012}

geodynamic nature require further studies and analysis of diamondiferous provinces worldwide.

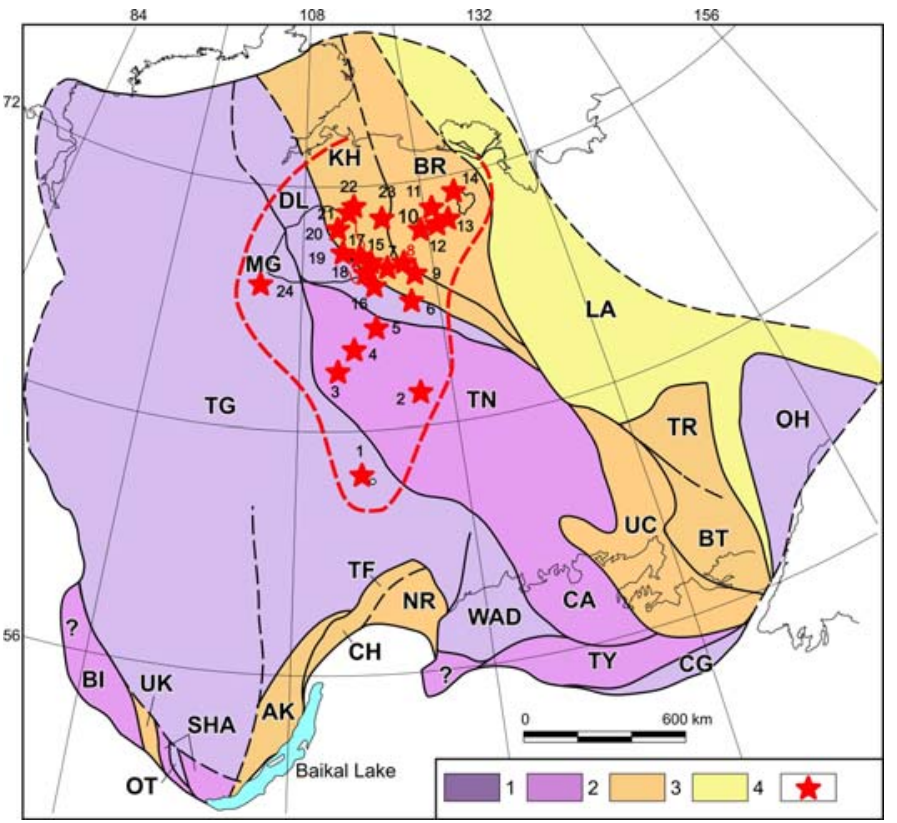

Fig .3. Geologic sketch map of the North Asian craton basement (Smelov and Timofeev, 2007) and position of kimberlite fields: 1 Archean, 2 - Archean and Paleoproterozoic, undifferentiated, 3 Paleoproterozoic, 4 - Mesoproterozoic; 5 - kimberlite fields (see Fig. 1 for numeration). Precambrian terranes: West Aldan (WA), Central Aldan (CA), Uchur (UC), Batomga (BT), Chogar (CG), Tynda (TY), Daldyn (DL), Khapchan (KH), Magan (MG), Akitkan (AK), Chuya (CH), Nechera (NR), Tondo (TF), Sharyzhalgay (SHA), Onot (OT), Urik-Liya (UL), Biryusa (BI), Tunguska (TG), Tyung (TN), Birekta (BR), Tyryn (TR), Lena-Aldan (LA).

\section{References}

Brakhfogel', F.F (1984) Geological aspects of kimberlite magmatism in the northeastern Siberian platform. Yakutsk:YaF SO AN SSSR. (in Russian).

Ilupin, I.P et al. (1990) Kimberlites: reference book. Moscow: published by "Nedra”. (in Russian).

Khar'kiv, A.D et al., (1998) Primary diamond deposits of the world. Moscow: OAO, published by "Nedra". (in Russian).

Smelov, A.P and Timofeev, V.F (2007). The age of the North Asian cratonic basement: An overview. Gondwana Research, V. 12, p. 279-288.

Zaitsev, A.I and Smelov, A.P (2010). Isotope geochronology of rocks of kimberlite formation in the Yakutian province. Yakutsk: published by Offset. (in Russian).
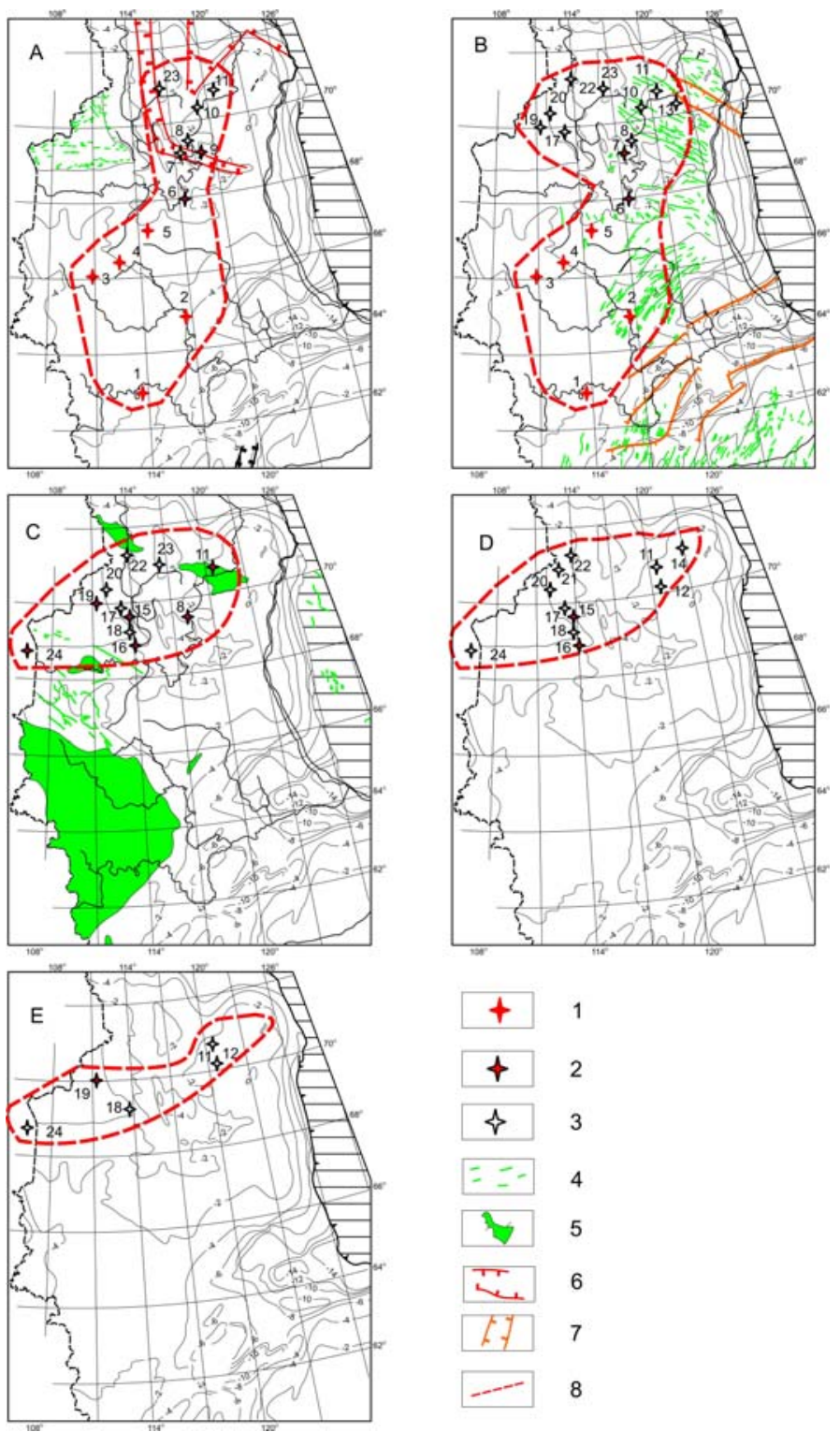

Fig.4. Extent of kimberlite magmatism in different time spans: A Ordovician-Silurian, B - Devonian-Carboniferous, C - Triassic, D Jurassic, E - Cretaceous. Kimberlite fields (1-3): 1 - high-grade, 2 low-grade, 3 - barren; 4 - dikes of Riphean, Paleozoic and Mesozoic diabase and dolerite; 5 - Permo-Triassic traps, 6 - Meso - and Neoproterozoic rift boundaries, 7 - Devonian rift boundaries, 8 boundaries of kimberlite magmatism areas. Shown are depth contours of the crystalline basement surface (in $\mathrm{km}$ ). Names of kimberlite fields are given in Fig. 1.

\section{Extended Abstract}

